\title{
KUALITAS HIDUP PASIEN DENGAN PENYAKIT KARDIOVASKULAR DI YOGYAKARTA
}

\author{
Jumayanti', Anggi Lukman Wicaksana, ${ }^{2,3}$, Eri Yanuar Akhmad Budi \\ Sunaryo ${ }^{4}$ \\ ${ }^{1}$ Program Studi Ilmu Keperawatan, Fakultas Kedokteran, Kesehatan Masyarakat \\ dan Keperawatan Universitas Gadjah Mada, Yogyakarta, Indonesia \\ Jl. Farmako Sekip Utara, Yogyakarta 55281 \\ Email: 1jumayanti32@gmail.com \\ ${ }^{2}$ Departemen Keperawatan Medikal Bedah, Fakultas Kedokteran, Kesehatan \\ Masyarakat dan Keperawatan Universitas Gadjah Mada, Yogyakarta, Indonesia \\ Jl. Farmako Sekip Utara, Yogyakarta 55281 \\ ${ }^{3}$ The Sleman Health Demographic and Surveillance System, Fakultas Kedokteran, \\ Kesehatan Masyarakat dan Keperawatan, Universitas Gadjah Mada, Yogyakarta \\ Email: ${ }^{2}$ anggi.l.wicaksana@ugm.ac.id \\ ${ }^{4}$ Freelance, Yogyakarta, Indonesia \\ Email: ${ }^{4}$ eri.yanuar02@gmail.com
}

Tanggal Submisi: 25 November 2019; Tanggal Penerimaan: 12 Mei 2020

\begin{abstract}
ABSTRAK
Kualitas hidup merupakan indikator utama bagi penyakit kardiovaskular. Penyakit kardiovaskular mendominasi dan menjadi penyakit utama penyebab kematian di Indonesia. Tujuan penelitian ini adalah untuk mengidentifikasi gambaran kualitas hidup pada pasien dengan penyakit kardiovaskular di Mlati, Yogyakarta. Penelitian ini adalah jenis penelitian deskriptif kuantitatif dengan desain crosssectional. Penelitian dilakukan pada pasien dengan penyakit kardiovaskular yang berada di wilayah Puskesmas Mlati, Sleman, Yogyakarta. Pengambilan sampel menggunakan teknik multistage cluster sampling. Data diambil menggunakan kuesioner Medical Outcome Study 12-Item Short-Form Second-Version (MOS SF-12v2). Analisis data menggunakan tabel distribusi frekuensi terdiri dari rerata, standar deviasi dan frekuensi. Hasil penelitian menunjukkan bahwa terdapat 107 responden yang berpartisipasi. Jumlah responden per-penyakit, hipertensi $(\mathrm{n}=$ $97)$, stroke $(n=13)$, gagal jantung $(n=12)$ dan penyakit jantung koroner $(n=7)$. Gambaran demografi mayoritas usia $\geq 45$ tahun; perempuan (63.6\%), pendidikan terakhir SMP (30.8\%), tidak bekerja (66\%), pendapatan rendah $(78.5 \%)$ dan menikah $(72.9 \%)$. Nilai kualitas hidup pada aspek fisik yaitu $42 \pm 9.88$ dan $56 \pm$ 9.87 untuk aspek mental. Nilai kualitas hidup pada sub-domain vitality (61.67 \pm 10.76) dan general health $(35.19 \pm 7.31)$ menduduki nilai tertinggi dan terendah. Skor kualitas hidup lebih tinggi pada domain mental daripada domain fisik.
\end{abstract}

Kata kunci: Domain mental, Domain fisik, Kualitas hidup, Penyakit kardiovaskular

ISSN 1979-7621 (Print). ISSN 2620-7761 (Online). 


\begin{abstract}
Quality of life is main indicator for cardiovascular diseases. It dominates and results in leading-cause of death in Indonesia. The objective of the research was to identify quality of life on patients with CVDs in Mlati, Yogyakarta. Descriptive quantitative study with cross-sectional design was used. This study was conducted in public health care unit of Mlati, Yogyakarta. Multistage cluster sampling based on the village area was used. Data were collected using Medical Outcome Study 12 Items Short-Form Second -Version (MOS SF-12v2) and analyzed using descriptive statistics as mean, standard deviation and frequency. The results displayed that as much as 107 patients with CVDs were participated. Patient with hypertension $(n=97)$ was known as the major CVDs, followed by stroke $(n=13)$, heart failure $(n=12)$, and coronary heart disease $(n=7)$. The majority of demoghraphic features included age $\geq 45$ year-old, female $(63.6 \%)$, basic education (59.8\%), unemployee (66\%), low income $(78.5 \%)$, and marriage (72.9\%). Quality of life consisted of physical component summary (PCS, M = 42 \pm 9.88 ) and mental component summary (MCS, $M=56 \pm 9.87)$. Among the eight subdomains of quality of life, vitality subdomain (VT, $M=61.67 \pm 10.76$ ) was the highest score whereas general health subdomain $(\mathrm{GH}, \mathrm{M}=35.19 \pm 7.31)$ was the lowest score. The conclusion of the study is MCS of quality of life showed higher than PCS.
\end{abstract}

Keywords: Cardiovascular diseases, Mental domain, Physial domain, Quality of life

\section{PENDAHULUAN}

Penyakit kardiovaskular merupakan penyakit tidak menular penyebab kematian nomor satu di dunia. Pada tahun 2012, sejumlah 17,5 juta jiwa meninggal karena penyakit kardiovaskular atau sekitar $31 \%$ dari seluruh kematian di dunia (World Health Organization, 2016). Lebih dari tiga per empat atau sekitar $80 \%$ dari kematian akibat penyakit kardiovaskular terjadi di negara berpenghasilan rendah sampai menengah termasuk Indonesia (WHO, 2016; American Hearth Association \& American Stroke Association, 2015). Kemenkes RI (2014) mendefinisikan penyakit kardiovaskular sebagai penyakit dengan gangguan pada jantung dan pembuluh darah seperti penyakit jantung koroner, gagal jantung, hipertensi dan stroke. Pada tahun 2013 prevalensi penyakit kardiovaskular di Indonesia sebesar $1,5 \%$ untuk penyakit jantung koroner, $12,1 \%$ stroke, $9,5 \%$ hipertensi dan $0,3 \%$ gagal jantung (Kemenkes RI, 2014). Data dari seluruh rumah sakit di Daerah Istimewa Yogyakarta menunjukkan bahwa penyakit kardiovaskular menjadi penyebab kematian utama dengan jumlah kematian yang semakin meningkat setiap tahun (Dinas Kesehatan DIY, 2013).

Penyakit kardiovaskular dapat menyebabkan kecacatan dan penurunan kualitas hidup terkait kesehatan (Department of Health, 2013; Community and Clinical Connections for Prevention and Health Branch, 2015; Ko dkk, 2015; Chin dkk, 2014; Ghojazadeh, 2015; Jurklewicz dkk, 2014; Hong 2015). Penilaian kualitas hidup terkait kesehatan sangat berguna dalam menentukan manajemen terkait penyakit yang diderita dan berguna untuk mengukur atau mengevaluasi tujuan yang telah tercapai (Ko dkk, 2015; Chin dkk, 2014). Tenaga kesehatan klinis dan publik telah 
menggunakan kualitas hidup untuk mengukur efek penyakit kronis, perawatan dan disabilitas jangka pendek maupun jangka panjang (Foundation Health Measure Report, 2010). Analisis data hasil survey kualitas hidup terkait kesehatan bermanfaat dalam mengidentifikasi sub-kelompok dengan persepsi kesehatan yang buruk dan memberikan intervensi guna meningkatkan kondisi kesehatan serta menghindari konsekuensi yang lebih serius (Centers for Disease Control and Prevention, 2016).

Indonesia memiliki penelitian yang terbatas mengenai kualitas hidup dengan spesifik penyakit kardiovaskular. Penelitian yang terbatas mengenai kualitas hidup pada pasien dengan penyakit kardiovaskular menjadikan data kurang komprehensif seperti hanya pada kelompok umur lansia. Fakta di lapangan juga menyatakan belum ada penelitian mengenai kualitas hidup pada pasien dengan penyakit kardiovaskular khususnya di Kecamatan Mlati, Sleman Yogyakarta. Untuk itu penelitian ini bertujuan untuk mengidentifikasi gambaran demografi dan kualitas hidup pada pasien dengan penyakit kardiovaskular meliputi penyakit jantung koroner, gagal jantung, hipertensi dan stroke di Puskesmas Mlati Yogyakarta.

\section{METODE PENELITIAN}

\section{Rancangan Penelitian dan Responden}

Penelitian ini merupakan penelitian deskriptif kuantitatif dengan desain crosssectional. Penelitian dilakukan di wilayah Puskesmas Mlati I dan II, Kabupaten Sleman, Daerah Istimewa Yogyakarta (DIY), Indonesia. Pengambilan data penelitian dilakukan September sampai Oktober 2017. Populasi dalam penelitian ini adalah semua pasien dengan penyakit kardiovaskular yang ada di wilayah kerja Puskesmas Mlati I dan II.

Kriteria inklusi dalam penelitian ini adalah: (1) semua pasien yang terdiagnosa penyakit kardiovaskular (seperti penyakit jantung koroner, gagal jantung, hipertensi, dan stroke); (2) dewasa (> 18 tahun); (3) pasien tinggal di wilayah kerja yaitu Kecamatan Mlati; (4) bersedia terlibat dalam penelitian. Kriteria eksklusi yaitu pasien dengan: (1) gangguan mental; (2) gangguan kognitif; dan (3) susah bekerjasama (seperti pasien yang memiliki gangguan motorik).

\section{Metode Pengambilan Data dan Sampling}

Pengambilan sampel menggunakan tehnik probability sampling jenis multistage cluster sampling.

Besar sampel ditentukan dengan rumus Lameshow (Dahlan, 2016):

$\mathrm{rl}=\frac{\mathrm{Z} \mathrm{c}^{2} \mathrm{P} Q \mathrm{Q}}{\mathrm{d}^{2}}=\frac{(1,96)^{2}(0,5)(0,5)}{(0,10)^{2}}=96$

Keterangan: P: Proporsi pasien dengan penyakit kardiovaskuler adalah $0.5, \mathrm{Z} \alpha$ : Nilai standar alpha 5\% adalah 1.96, Q: (1-P) $=(1-0.5)=0.5, \mathrm{~d}$ : Presisi (kesalahan dalam memprediksi proporsi berdasarkan prinsip logis dan mampu laksana) adalah $10 \%$. Koreksi besar sampel menggunakan rumus (Sastroasmoro \& Ismael, 2010):

$$
\mathrm{r}^{\prime}=\frac{\pi}{(1-\overline{0})}=\frac{96}{(1-0.1)}=107
$$

Keterangan: n: besar sampel yang dihitung, $\mathrm{f}$ : perkiraan proporsi drop out $=10 \%$.

Penelitian ini menggunakan kuesioner karakteristik responden dan Medical Outcome Study 12-Item Short-Form Health Survey (MOS SF12). Kuesioner MOS SF12 versi 2 (MOS SF12v2) dikembangkan oleh John E. Ware pada tahun 2002 dan memiliki 2 domain yaitu fisik (physical health component) dan mental (mental health component).

Domain fisik terdiri dari 4 subdomain yaitu physical functioning (PF), role-physical (RP), bodily pain (BP), dan general health $(\mathrm{GH})$. Domain mental terdiri dari 4 subdomain meliputi vitality (VT), social functioning (SF), role-emotional (RE), dan mental health $(\mathrm{MH})$. Rentang nilai akhir berkisar antara 0-100. Nol (0) menggambarkan kualitas hidup yang paling buruk, dan 100 menggambarkan kualitas hidup yang paling baik (Ware dkk, 1995). Kuesioner MOS SF12v2 versi Indonesia 
telah divalidasi dan dilakukan identifikasi tingkat keajegan (Wicaksana dkk, 2020).

\section{Analisis Data}

Analisis data menggunakan analisis univariat dengan tabel distribusi frekuensi. Pengolahan data untuk mengidentifikasi gambaran domain dan subdomain menggunakan software komputer yang sebelumnya sudah dimasukan formula sesuai interpretasi MOS SF12v2.

\section{HASIL DAN PEMBAHASAN}

Berdasarkan hasil multistage cluster sampling, desa terpilih yang menjadi tempat pengambilan data adalah desa Sumberadi. Pemilihan desa dilakukan dengan random menggunakan teknik manual berupa undian. Waktu pengambilan data dilakukan September hingga Oktober 2017. Total pasien yang dimintai untuk terlibat sebanyak 109 dengan 2 pasien yang menolak dan 107 responden yang dianalisis. Total 107 responden penyakit kardiovaskular yang terlibat dalam penelitian ini terdiri dari 97 responden dengan hipertensi, 12 gagal jantung, 13 stroke dan 7 penyakit jantung koroner. Dua pasien yang menolak berpartisipasi dalam penelitian ini dikarenakan alasan penolakan dari anggota keluarga.

\section{Data Demografi Responden}

Berdasarkan Tabel 1 rata-rata usia responden 59 tahun; mayoritas berjenis kelamin perempuan; mayoritas pendapatan di bawah Rp 1.000.000,00; dan mayoritas menikah.

Responden dengan penyakit kardiovaskular banyak ditemukan pada kelompok usia 55-64 tahun. Hal ini berkaitan dengan semakin bertambahnya usia, maka kerentanan terhadap risiko penyakit kardiovaskular semakin meningkat karena elastisitas pembuluh darah arteri yang semakin menurun sehingga meningkatkan kejadian hipertensi (Amu, 2013). Hasil ini didukung oleh data Kementrian Kesehatan RI
(2014) menyatakan bahwa pada tahun 2013, pasien dengan penyakit kardiovaskular seperti jantung koroner, gagal jantung, dan stroke banyak pada kelompok usia 45-54, 5564 dan 65-74 tahun. Rochmayanti (2017) menyatakan bahwa rata-rata usia responden penyakit jantung koroner adalah 58,74 tahun. Penelitian Hsu dkk (2014) menyebutkan bahwa pasien dengan penyakit kardiovaskular banyak ditemukan pada kelompok usia 65-75 tahun. Ortiz dkk, (2016) menemukan rata-rata usia responden dengan risiko sedang penyakit kardiovaskular yaitu 60,48 tahun.

Mayoritas responden berjenis kelamin perempuan. Hasil ini dapat terjadi kemungkinan karena perempuan lebih rentan mengalami penyakit kardiovaskular ketika menopause akibat adanya penurunan hormon estrogen. Selain itu, kemungkinan disebabkan oleh faktor usia yaitu mayoritas responden berusia $>45$ tahun yang menjadi faktor terjadinya menopause. Usia menopause terjadi pada 40-60 tahun (Syalfina, 2017). Estrogen berperan pada sistem kardiovaskular. Estrogen dapat menurunkan kadar lipid dalam serum, yang jika kadarnya tinggi dapat berkontribusi terjadi aterosklerosis. Estrogen juga berperan penting dalam meningkatkan lipoprotein lipase yang mana berperan penting dalam metabolisme energi dan asam lemak pada jantung (Wend, 2012). Penelitian sebelumnya menunjukan bahwa proporsi perempuan lebih banyak daripada laki-laki. Penelitian di Taiwan, Spanyol dan Korea menunjukan bahwa pasien dengan penyakit kardiovaskular dan orang yang berisiko terhadap penyakit kardiovaskular mayoritas adalah perempuan (Hsu dkk, 2014; Ortiz dkk, 2016; Hong, 2015; Amu, 2013).

Penelitian hipertensi di Indonesia oleh Dewi \& Sudhana (2014) dan Sari dkk (2017) menyatakan bahwa mayoritas responden adalah perempuan dengan presentase $65,5 \%$ dan $68,2 \%$. Wanita dinyatakan memiliki masalah terkait risiko penyakit kardiovaskular lebih tinggi dibandingkan laki-laki (Sun dkk, 2015; Aini dkk, 2019). 
Tabel 1. Data Demografi Responden Berdasarkan Jenis Penyakit Kardiovaskular ( $\mathrm{N}=107)$

\begin{tabular}{|c|c|c|c|c|c|}
\hline \multirow[t]{2}{*}{ Data } & \multicolumn{5}{|c|}{ Mean \pm SD atau n (\%) } \\
\hline & $\begin{array}{c}\text { Total } \\
(\mathrm{n}=107)\end{array}$ & $\begin{array}{c}\mathbf{H t} \\
(\mathrm{n}=97)\end{array}$ & $\underset{(n=13)}{\mathbf{S t}}$ & $\begin{array}{c}\mathbf{G J} \\
(\mathrm{n}=12)\end{array}$ & $\begin{array}{l}\text { PJK } \\
(\mathrm{n}=7)\end{array}$ \\
\hline \multicolumn{6}{|l|}{$\begin{array}{l}\text { Rentang usia: } \\
35-100 \text { (tahun) }\end{array}$} \\
\hline Rata-rata: & $59,31 \pm 11,08$ & $59,29 \pm 11,16$ & $62,77 \pm 7,82$ & $62,92 \pm 9,69$ & $59,14 \pm 14,95$ \\
\hline $35-44$ & $9(8,411 \%)$ & $(9,28 \%)$ & $(0 \%)$ & $(0 \%)$ & $(0 \%)$ \\
\hline $45-54$ & $26(24,30 \%)$ & $22(22,68 \%)$ & $2(15,38 \%)$ & $2(16,67 \%)$ & $4(57,14 \%)$ \\
\hline $55-64$ & $37(34,58 \%)$ & $35(36,08 \%)$ & $4(30,77 \%)$ & $4(33,33 \%)$ & $(0 \%)$ \\
\hline $65-74$ & $28(26,17 \%)$ & $25(25,77 \%)$ & $7(53,85 \%)$ & $5(41,67 \%)$ & $1(14,29 \%)$ \\
\hline$\geq 75$ & $7 \quad(6,54 \%)$ & $6 \quad(6,18 \%)$ & $(0 \%)$ & $1(8,33 \%)$ & $2(28,57 \%)$ \\
\hline \multicolumn{6}{|l|}{ Jenis kelamin } \\
\hline Laki-laki & $39(36,45 \%)$ & $33(34,02 \%)$ & $6(46,15 \%)$ & $3(25,00 \%)$ & $6(85,71 \%)$ \\
\hline Perempuan & $68(63,55 \%)$ & $64(65,98 \%)$ & $7(53,85 \%)$ & $9(75,00 \%)$ & $1(14,29 \%)$ \\
\hline \multicolumn{6}{|l|}{ Pendidikan } \\
\hline Tidak sekolah & $19(17,76 \%)$ & $18(18,56 \%)$ & $4(30,77 \%)$ & $2(16,67 \%)$ & $1(14,29 \%)$ \\
\hline SD & $31(28,97 \%)$ & $28(28,87 \%)$ & $3(23,08 \%)$ & $5(41,67 \%)$ & $1(14,29 \%)$ \\
\hline SMP & $33(30,84 \%)$ & $32(32,99 \%)$ & $2(15,38 \%)$ & $2(16,67 \%)$ & $2(28,57 \%)$ \\
\hline SMA & $19(17,76 \%)$ & $16(16,49 \%)$ & $2(15,38 \%)$ & $2(16,67 \%)$ & $2(28,57 \%)$ \\
\hline S1 & $5 \quad(4,67 \%)$ & $3 \quad(3,09 \%)$ & $2(15,38 \%)$ & $1(8,33 \%)$ & $1(14,29 \%)$ \\
\hline \multicolumn{6}{|l|}{ Pekerjaan } \\
\hline Tidak & $71(66,36 \%)$ & $61(62,89 \%)$ & $11(84,62 \%)$ & $12(100 \%)$ & $7(100 \%)$ \\
\hline bekerja/pensiun & & & & & \\
\hline Bekerja & $36(33,64 \%)$ & $36(37,11 \%)$ & $2(15,38 \%)$ & $(0 \%)$ & $0 \quad(0 \%)$ \\
\hline \multicolumn{6}{|l|}{ Pendapatan } \\
\hline$<1$ juta & $84(78,50 \%)$ & $77(79,38 \%)$ & $1184,62 \%)$ & $9(75,00 \%)$ & $7(100 \%)$ \\
\hline $1-2$ juta & $12(11,21 \%)$ & $11(11,34 \%)$ & $(0 \%)$ & $1 \quad(8,33 \%)$ & $(0 \%)$ \\
\hline 2-3 juta & $3 \quad(2,80 \%)$ & $3 \quad(3,09 \%)$ & $(0 \%)$ & $0 \quad(0 \%)$ & $(0 \%)$ \\
\hline 3-4 juta & $6 \quad(5,61 \%)$ & $4 \quad(4,12 \%)$ & $(7,69 \%)$ & $2(16,67 \%)$ & $(0 \%)$ \\
\hline 4-5 juta & $2 \quad(1,87 \%)$ & $2(2,06 \%)$ & $1 \quad(7,69 \%)$ & $0 \quad(0 \%)$ & $(0 \%)$ \\
\hline \multicolumn{6}{|l|}{ Status } \\
\hline \multicolumn{6}{|l|}{ Pernikahan } \\
\hline $\begin{array}{l}\text { Lajang/duda/ } \\
\text { janda/terpisah }\end{array}$ & $29(27,10 \%)$ & $27(27,84 \%)$ & $2(15,38 \%)$ & $5(41,67 \%)$ & $(0 \%)$ \\
\hline Menikah & $78(72,90 \%)$ & $70(72,16 \%)$ & $11(84,62 \%)$ & $7(58,33 \%)$ & $7(100 \%)$ \\
\hline
\end{tabular}

Keterangan: \%: persentase, GJ: gagal jantung, $\mathrm{Ht}$ : hipertensi, mean: rata-rata, $\mathrm{N}$ : total responden penyakit kardiovaskular, n: jumlah responden, PJK: penyakit jantung koroner, S1: strata-1, SD: sekolah dasar, SMA: sekolah menengah atas, SMP: sekolah menengah pertama, St: stroke.

Tingkat pendidikan responden banyak ditemukan dengan lulusan Sekolah Menengah Pertama (SMP) atau lebih rendah. Berdasarkan data Badan Pusat Statistik, hasil sensus 2010, wilayah DIY memiliki persentase penduduk yang tidak atau belum pernah sekolah $(9,99 \%)$, tidak/belum tamat sekolah dasar (SD, 15,21\%), tamat SD $(21,33 \%)$, dan tamat SMP sederajat $(16,45 \%)$, sehingga total pendidikan SMP atau lebih rendah yaitu $62,98 \%$. Selain itu, tempat diambilnya penelitian yaitu desa 
Sumberadi merupakan tempat pedesaan. Pedesaan diketahui memiliki kualitas sumber daya manusia yang lebih rendah daripada perkotaan yang dapat dilihat berdasarkan pendidikan yang ditamatkan (Badan Pusat Statistik, 2010). Semakin tinggi tingkat pendidikan, maka semakin tinggi tingkat pengetahuan. Pengetahuan yang tinggi akan menimbulkan pemahaman serta kesadaran yang tinggi akan hidup sehat dan bahaya penyakit seperti penyakit kardiovaskular. Diketahui bahwa pendidikan yang rendah dapat mengakibatkan pengetahuan mengenai kesehatan juga rendah. Hal ini dikarenakan adanya kesulitan atau keterlambatan dalam menerima informasi atau penyuluhan sehingga berdampak terhadap pola hidup atau perilaku yang tidak sehat (Anggaran \& Prayitno, 2013). Penelitian yang serupa dari Hsu dkk (2014) dan Chin dkk (2014) menyatakan bahwa pendidikan lansia dengan penyakit kardiovaskular mayoritas adalah lulusan SD dan SMP.

Lebih dari $50 \%$ responden memiliki status tidak bekerja atau pensiunan. Hasil penelitian ini kemungkinan karena mayoritas umur masyarakat di desa Sumberadi adalah > 45 tahun yang merupakan golongan usia tua. Usia tua bisa menjadi alasan bahwa pasien banyak yang pensiunan. BPS (2010) menyatakan median penduduk provinsi DIY pada tahun 2010 yaitu 32,05 yang menunjukan termasuk kategori tua. Tidak bekerja berhubungan positif dengan tekanan darah sistolik pada laki-laki dan berhubungan positif dengan obesitas, tekanan darah sistolik dan aktivitas fisik yang tidak cukup pada perempuan. Pada negara berpenghasilan menengah ke bawah, perempuan yang mengganggur atau tidak bekerja menjadi faktor risiko yang tinggi terhadap penyakit kardiovaskular. Hal tersebut dikarenakan lama waktu yang dihabiskan oleh wanita ketika di rumah seperti membersihkan rumah, mengurus anak dan lain-lain sehingga waktu untuk beraktivitas di luar rumah menjadi berkurang (Sun dkk, 2015). Chin dkk (2014) mendapatkan bahwa pasien dengan penyakit kardiovaskular yang tidak bekerja lebih banyak daripada yang bekerja dengan persentase $73,3 \%$. Hasil yang mendukung juga didapat dari penelitian di Indonesia bahwa responden dengan hipertensi lebih banyak tidak bekerja daripada bekerja dengan perbandingan 2:1 (Dewi \& Sudhana, 2014; Sari dkk, 2017).

Mayoritas pendapatan responden adalah kurang dari $\mathrm{Rp} 1.000 .000,00$ per bulan. Hasil ini kemungkinan karena mayoritas responden pendidikan rendah (SMP atau lebih rendah). Pendidikan yang rendah dapat berkontribusi dalam memperoleh jenis pekerjaan yang bisa menghasilkan pendapatan lebih tinggi. Selain itu, hasil ini sebanding dengan data bahwa mayoritas responden penelitian ini adalah tidak bekerja/pensiunan, sehingga pendapatan menjadi rendah. Status sosialekonomi yang rendah juga berdampak pada meningkatnya kejadian hipertensi. Pendapatan yang rendah berhubungan dengan faktor risiko perilaku dengan memiliki hambatan yang lebih tinggi dalam memodifikasi perilaku berisiko seperti berhenti merokok, meningkatkan diet dan aktivitas fisik. Contoh hambatannya seperti akses, biaya dan rujukan kesehatan (Fiscella \& Tancredi, (2008). Sari dkk (2017) menyatakan bahwa sekitar $58,9 \%$ pasien hipertensi memiliki penghasilan kurang dari Rp 500.000,00 per bulan. Cho dkk (2012) menyatakan bahwa terdapat hubungan yang signifikan antara rendahnya pendapatan dengan faktor risiko penyakit kardiovaskular. Mayoritas status pernikahan responden adalah menikah. Hal ini kemungkinan berkaitan dengan usia yaitu mayoritas responden berusia $>45$ tahun. Hal ini menunjukan bahwa pada usia $>45$ tahun umumnya masyarakat Indonesia sudah menikah. Rata-rata umur pernikahan pertama pada penduduk di DIY yaitu 28,3 tahun untuk laki-laki dan 24,3 tahun untuk perempuan (BPS, 2010). Penelitian pada responden dengan risiko penyakit kardiovaskular ditemukan mayoritas menikah (Ko dkk, 2015). Aburuz dkk (2015) menyatakan bahwa responden dengan gagal jantung mayoritas berstatus menikah dengan presentase $61,2 \%$. Hal yang serupa 
didapatkan dari penelitian di Indonesia oleh Dewi \& Sudhana (2012) \& Rochmayanti (2011) bahwa pada responden dengan hipertensi dan jantung koroner mayoritas responden berstatus menikah. Hal ini juga sejalan dengan hasil penelitian Lammintausta (2013) bahwa total responden penyakit kardiovaskular di Finlandia yang berusia 3599 tahun mayoritas berstatus menikah. Diniz dkk (2013) juga menambahkan sekitar 78 $(58,2 \%)$ responden penyakit kardiovaskular berstatus menikah atau tinggal bersama pasangan.

\section{Data Kualitas Hidup Responden}

Tabel 2. Kualitas Hidup Responden Dengan Penyakit Kardiovaskular (N=107)

\begin{tabular}{lllllllllll}
\hline & MCS & PCS & VT & MH & PF & SF & RE & BP & RP & GH \\
\hline Total & 56,07 & 42,21 & 61,67 & 57,31 & 49,32 & 48,36 & 47,25 & 46,20 & 44,69 & 35,19 \\
$(\mathrm{n}=107)$ & $(9,87)$ & $(9,88)$ & $(10,76)$ & $(9,84)$ & $(10,91)$ & $(11,62)$ & $(11,92)$ & $(11,71)$ & $(12,09)$ & $(7,31)$ \\
Ht $(\mathrm{n}=97)$ & 55,95 & 42,56 & 61,86 & 57,19 & 49,74 & 48,45 & 47,26 & 46,20 & 45,02 & 35,32 \\
& $(9,91)$ & $(9,76)$ & $(10,54)$ & $(10,03)$ & $(10,61)$ & $(11,44)$ & $(12,13)$ & $(12,08)$ & $(11,79)$ & $(7,48)$ \\
St $(\mathrm{n}=13)$ & 57,38 & 39,59 & 57,81 & 56,57 & 43,25 & 46,47 & 50,92 & 44,90 & 44,42 & 39,60 \\
& $(9,94)$ & $(14,67)$ & $(12,99)$ & $(10,38)$ & $(13,41)$ & $(17,49)$ & $(8,68)$ & $(13,26)$ & $(13,32)$ & $(10,29)$ \\
GJ $(\mathrm{n}=12)$ & 56,71 & 37,05 & 59,49 & 54,38 & 44,30 & 46,47 & 49,56 & 42,17 & 40,67 & 33,24 \\
& $(8,51)$ & $(10,10)$ & $(13,46)$ & $(10,18)$ & $(14,40)$ & $(14,28)$ & $(10,07)$ & $(11,08)$ & $(15,65)$ & $(7,02)$ \\
PJK $(\mathrm{n}=7)$ & 59,18 & 38,80 & 62,13 & 61,06 & 46,65 & 49,36 & 46,49 & 47,25 & 38,75 & 35,81 \\
& $(7,59)$ & $(9,00)$ & $(7,92)$ & $(4,80)$ & $(12,57)$ & $(9,60)$ & $(10,06)$ & $(8,32)$ & $(14,07)$ & $(5,76)$ \\
\hline
\end{tabular}

Keterangan: BP: bodily pain, GH: general health, GJ: gagal jantung, Ht: hipertensi, MCS: mental health component summary, $\mathrm{MH}$ : mental health, $\mathrm{N}$ : total responden dengan penyakit kardiovaskular, n: jumlah responden, PCS: physical health component summary, PF: physical function, PJK: penyakit jantung koroner, RE: role emotional, RP: role-physical, SF: social functioning, St: stroke, VT: vitality.

Kualitas hidup responden dengan penyakit kardiovaskular pada domain fisik didapat skor 42,21 $(\mathrm{SD}=9,88)$ sedangkan domain mental dengan skor 56,07 (SD = 9,87). Skor kualitas hidup responden penyakit kardiovaskular tertinggi pada subdomain VT sedangkan terendah pada subdomain GH. Hasil skor kualitas hidup subdomain pada keempat penyakit meliputi hipertensi, gagal jantung, stroke dan penyakit jantung koroner juga memiliki nilai yang hampir sama dimana skor tertinggi pada subdomain VT dan terendah pada subdomain GH.

Rata-rata kualitas hidup pasien dengan penyakit kardiovaskular lebih tinggi pada domain mental (MCS) dibandingkan domain fisik (PCS) dengan hasil 56,07 dan 42,21. Domain fisik (PCS) terdiri dari sub domain physical functioning (PF), rolephysical (RP), bodily pain (BP), dan general health $(\mathrm{GH})$ sedangkan domain mental (MCS) meliputi vitality (VT), social functioning (SF), role emotional (RE), dan mental health $(\mathrm{MH})$. Skor kualitas hidup pada domain fisik yang rendah berkaitan dengan jenis penyakit yang diderita. Penyakit kardiovaskular merupakan penyakit kronis dan degeneratif yang menyebabkan masalahmasalah fisik sehingga muncul keterbatasanketerbatasan dalam melakukan aktivitas fisik sehari-hari. Akan tetapi pada domain mental, kemungkinan selain bisa dipengaruhi oleh jenis penyakit juga berkaitan dengan aspek lain seperti spiritual. Khotimah dkk (2016) menyatakan bahwa mayoritas lansia di beberapa kabupaten Yogyakarta meyakini peran agama dalam kehidupannya dan memiliki dimensi mental spiritual yang tinggi dalam hal kepedulian terhadap masa depan. Hal ini bisa menggambarkan bahwa tingginya tingkat spiritualitas pada lansia di Yogyakarta. Religius atau spiritual dapat meningkatkan kepatuhan, kepuasan dalam hidup dan peningkatan kesehatan (Almeida dkk, 2014; Hefti, 2011). Penelitian lain 
menambahkan terdapat hubungan antara peningkatan kecerdasan spiritual terhadap kesehatan mental yang lebih baik (Razaghi, 2017). Dengan demikian, berkaitan dengan hasil penelitian ini bahwa peningkatan skor kualitas hidup domain mental dapat dikarenakan tingkat spiritual responden yang tinggi sehingga mempengaruhi pandangan responden terhadap masalah emosional seperti cemas dan depresi akibat dari penyakit fisik yang diderita.

Hasil serupa ditemukan pada penelitian Ortiz dkk (2016) bahwa responden dengan risiko sedang penyakit kardiovaskular memiliki rerata skor domain MCS 49,44 sedangkan domain PCS 48,42. Hsu dkk (2014) menambahkan bahwa responden dengan penyakit kardiovaskular memiliki skor MCS 55,9 sedangkan PCS 46,0. Hal yang berbeda ditemukan pada penelitian Gorrian dkk (2013) bahwa rerata MCS 49,63 \pm 10,51 sedangkan PCS 51,62 \pm 8,07 . Hong (2015) juga menemukan skor domain fisik lebih tinggi daripada domain mental. Peningkatan skor domain fisik (PCS) dibandingkan domain mental (MCS) dikarenakan tingginya tingkat kecemasan dan depresi yang berhubungan dengan tingkat pendidikan yang rendah, serta status belum menikah (Hong, 2015; Gorrian dkk, 2013).

Skor kualitas hidup penyakit kardiovaskular paling tinggi 61,67 pada subdomain VT sedangkan terendah 35,19 pada GH. Subdomain GH mengambarkan kesehatan individu secara umum sedangkan subdomain VT menggambarkan seberapa banyak energi yang dimiliki oleh individu. Dari hasil penelitian ini, sub domain GH memiliki skor paling buruk. Kesehatan individu secara umum bisa dipengaruhi oleh berbagai hal seperti tingkat pendidikan. Pendidikan yang tinggi menjadi penting karena dapat mempengaruhi pilihan terkait gaya hidup dan perilaku kesehatan (Zimmerman, \& Woolf, 2014). Hal tersebut sesuai dengan hasil penelitian ini bahwa mayoritas pendidikan responden hanya lulusan SD dan SMP. Rendahnya pendidikan mempengaruhi rendahnya pengetahuan responden akan kesehatan sehingga kecenderungan memilki gaya hidup yang kurang baik dan mudah terkena penyakit kronis khususnya penyakit kardiovaskular. Dengan demikian berdampak juga pada kesehatan responden secara umum yaitu rendahnya skor subdomain GH. Hasil yang didapat sesuai dengan hasil penelitian Ortiz dkk (2016) yaitu skor terendah pada subdomain GH $(39,92 \pm 8,90)$ dan tinggi pada sub-domain VT $(50,90 \pm 11,13)$.

Analisa hasil penelitian menunjukkan bahwa responden dengan penyakit hipertensi, gagal jantung, stroke dan jantung koroner memiliki skor kualitas hidup tertinggi pada domain MCS dan terendah pada domain PCS. Penelitian Hsu dkk (2014) menyatakan hal yang sama yaitu skor paling tinggi terdapat pada domain MCS dibandingkan PCS pada responden dengan penyakit hipertensi dan stroke. Dewi \& Sudhana (2014) mendukung bahwa pasien hipertensi memiliki skor kualitas hidup yang buruk pada domain fisik $(62,1 \%)$, akan tetapi pada domain mental memiliki perbedaan dengan hasil penelitian saat ini bahwa terdapat skor kualitas hidup yang buruk juga pada domain mental (70,4 \%). Aburuz dkk (2015) menyatakan bahwa pasien gagal jantung memiliki skor kualitas hidup yang buruk pada kedua domain fisik (PCS) maupun mental (MCS).

Hasil penelitian mengindikasikan bahwa baik secara keseluruhan penyakit kardiovaskular maupun spesifik per penyakit seperti hipertensi, gagal jantung, stroke dan jantung koroner memiliki skor kualitas hidup di atas setengah $(>50)$ pada sub-domain VT dan MH. Jika ditinjau lebih dalam, responden dengan gagal jantung memiliki skor lebih buruk daripada hipertensi, jantung koroner dan stroke pada sub-domain GH. Hasil ini sesuai dengan penelitian lain bahwa rerata skor sub-domain GH pada pasien gagal jantung adalah 26,8 $\pm 12,5$ dan merupakan skor kualitas hidup paling buruk dari subdomain lain (Aburuz dkk, 2015).

Skor kualitas hidup responden penyakit kardiovaskular yang > 50 terdapat pada subdomain $\mathrm{MH}$ dan VT sedangkan yang < 50 pada PF, RP, BP, GH, SF, dan RE. 
Hal ini menggambarkan bahwa beberapa sub-domain kualitas hidup harus lebih diperhatikan lagi khususnya yang memiliki skor di bawah nilai 50. Aspek yang perlu ditingkatkan meliputi fungsi fisik, peran fisik, pengelolaan nyeri, tingkat kesehatan secara umum, dukungan sosial dan penanganan masalah emosional.

\section{KESIMPULAN}

Kualitas hidup pasien dengan penyakit kardiovaskular lebih tinggi pada domain mental (MCS) daripada fisik (PCS). Skor kualitas hidup paling tinggi pada sub domain VT dan terendah pada GH. Gagal jantung diketahui memiliki skor kualitas hidup paling buruk dibandingkan penyakit lain dalam aspek kesehatan secara umum (GH). Secara umum, aspek kualitas hidup yang perlu ditingkatkan pada pasien dengan penyakit kardiovaskular meliputi fungsi fisik, peran fisik, pengelolaan nyeri, tingkat kesehatan secara umum, dukungan sosial dan penanganan masalah emosional. Secara khusus, diperlukan adanya upaya peningkatan manajemen penyakit kardiovaskular dalam aspek fisik. Selanjutnya, perlu perhatian penuh terhadap peningkatan aspek general health yang menunjukan skor paling rendah pada pasien dengan penyakit kardiovaskular tanpa mengesampingkan aspek sub-domain lainnya.

\section{UCAPAN TERIMAKASIH}

Peneliti mengucapkan banyak terimakasih kepada Fakultas Kedokteran Universitas Gadjah Mada selaku penyandang dana hibah penelitian ini, asisten penelitian yang telah banyak membantu (Adhe Kurnia Destiana, I Putu Athia Alit Artawan, Vania Elysia Septiani, dan Lulu Lukitasari), dan Pak Dusun yang telah membantu dalam teknis pelaksanaan penelitian.

\section{DAFTAR PUSTAKA}

Aburuz, M.E., Alaloul, F., Saifan, A., Masa'Deh, R., \& Abusalem, S. (2015). Quality of Life for Saudi Patients with Heart Failure: A Cross-sectional Corelational Study. Global Journal of Health Science. 8(3): 49-58.

Aini, F.N., Wicaksana, A.L., Pangastuti, H.S. (2019). Tingkat Risiko Kejadian Kardiovaskular pada Penyandang Diabetes Mellitus Tipe 2. Jurnal Persatuan Perawat Nasional Indonesia. 4(3): 182-192.

Almeida, A.M., Koenig, H.G., Lucchetti, G. (2014). Clinical Implication of Spirituality to Mental Health: Review of Evidence and Practical Guidelines. Revista Brasileira de Psiquiatria. 36: 176-182.

American Hearth Association \& American Stroke Association. (2015). Hearth disease, stroke and research statistics at-alance. Tersedia dari http://www.heart.org/idc/groups/ahamahpublic/@wcm/@sop/@smd/documents/downl oadable/ucm_480086.pdf

Amu, D.A. (2013). Faktor-faktor yang Berhubungan dengan Hipertensi di Wilayah Perkotaan dan Pedesaan Indonesia Tahun 2013 [karya tulis ilmiah]. Jakarta: Universitas Islam Negeri Syarif Hidayatullah. 
Anggara, F.H.D., \& Prayitno, N. (2013). Faktor-faktor yang Berhubungan dengan Tekanan Darah di Puskesmas Telaga Murni Cikarang Barat Tahun 2012. Jurnal Ilmiah Kesehatan, 5 (1): 20-25.

Badan Pusat Statistik. (2010). Sensus Penduduk 2010 Provinsi DI Yogyakarta. Tersedia dari http://sp2010.bps.go.id/index.php/site?id=34\&wilayah=DI-Yogyakarta.

Centers for Disease Control and Prevention. (2016). Health-related Quality of Life Concepts. Tersedia dari https://www.cdc.gov/hrqol/concept.htm.

Chin, Y.R., Lee, I.S., \& Le, H.Y. (2014). Effects of Hipertension, Diabetes, and/or Cardiovascular Disease on Health-Related Quality of Life in Elderly Korean Individuals: A Population-Based Cross-Sectional Survey. Asian Nursing Research. 8 (4): 267-273.

Community and Clinical Connections for Prevention and Health Branch. (2015). Heart and Blood Vessel disease in north Carolina. Tersedia dari http://www.communityclinicalconnections.com.

Dahlan, M.S. (2016). Besar Sampel dalam Penelitian Kedokteran dan Kesehatan (edisi 4). Jakarta: Epidemiologi Indonesia.

Department of Health. (2013). Cardiovascular disease outcome strategy. United Kingdom: Department of Health. Tersedia dari https://www.gov.uk/government/uploads/system/uploads/attachment_data/file/217118/ 9387-2900853-CVD-Outcomes_web1.pdf.

Dewi, P.R. \& Sudhana, I.W. (2014). Gambaran Kualitas Hidup pada Lansia dengan Normotensi dan Hipertensi di Wilayah Kerja Puskesmas Gianyar I Periode Bulan November Tahun 2013. E-Jurnal Medika Udayana. 3(9): 1-13.

Diniz, M.A., Tavares, D.M.S. (2013). Risk Factors for Cardiovascular Disease in Aged Individuals in A City in The State of Minas Gerais. Text Context Nursing, Florianopolis. 22 (4): 885-92.

Dinas Kesehatan DIY. (2013). Profil Kesehatan Daerah Istimewa Yogyakarta. Tersedia dari http://www.depkes.go.id/resources/download/profil/PROFIL_KES_PROVINSI_2012/ 14_Profil_Kes.Prov.DIYogyakarta_2012.pdf.

Fiscella, K., \& Tancredi, D. (2008). Socioeconomic Status and Coronary Heart Disease Risk Prediction. National Institute of Health. 300 (22): 2666-2668.

Foundation Health Measure Report. (2010). Health-related Quality of Life and Well-being. Healthy people 2020, Tersedia dari https://www.healthypeople.gov/sites/default/files/HRQoLWBFullReport.pdf.

Ghojazadeh, M., Aghdash, S.A., \& Navi, Z.S. (2015). Cardiovascular Patient's Experiences of Living with Pacemaker: Qualitative Study. ARYA Atheroscler. 11(5): 281-288. 
Gorrian, C.M., Shane, C.M., Quade, C.M., Keelan, T., Neill, J.O., Galvin, J., Malone, K., Mahon, N.G., Codd, M. (2013). Family-based Associations in Measures of Psychological Distress and Quality of Life in A Cardiac Screening Clinic for Inheritable Cardiac Disease: A Cross Sectional Study. BMC Medical Genetic. 14: 1-8.

Hayes, C.J., Bhandari, N.R., Kathe, N., \& Payakachat, N. (2017). Reliability and Validity of the Medical Outcome Study Form-12 Version 2 (SF-12v2) in Adults with Non-cancer Pain. Healthcare. 5(22): 1-22.

Hefti, R. (2011). Integrating Religion and Spirituality Into Mental Health Care, Psychiatry and Psychotherapy. Religions. 2: 611-627.

Hong, E. (2015). Health-related Quality of Life and Health Condition of Community-dwelling Populations with Cancer, Stroke, and Cardiovascular Disease. The Society of Physical Therapy Science. 27: 2521-2524.

Hsu, N.W., Tsao, H.M., Chen, H.C., \& Chou, P. (2014). Anxiety and Depression Mediate the Health-Related Quality of Life Differently in Patients with Cardiovascular Disease and Stroke-Preliminary Report of The Yilan Study: A Population-Based Community Health Survey. PLoS One. 9(9): e107609.

Jurklewicz, B.S., Zakllczynskl, M., Owczarek, A., Partyka, R., Moscinskl, M., Pudlo, R., dkk. (2014). Low Health-Related Quality of Life is A Predictor of Major Adverse Cardiovascular Events in Patients With Chronic Nonischemic Hearth Failure. Heart and Lung Failure, Transplantology. 11(3): 283-288.

Kementrian Kesehatan RI. (2014). Situasi Kesehatan Jantung. Info Datin Pusat Data dan Informasi Kesehatan RI. Tersedia dari http://www.depkes.go.id/download.php?file=download/pusdatin/infodatin/infodatinjantung.pdf.

Khotimah, N., Gunardo, R.B., Ghufron, A., Sugiharti, S., Aryekti, K. (2016). Lanjut Usia (lansia) Peduli Masa Depan di Daerah Istimewa Yogyakarta. Geomedia. 14 (2): 51-66.

Ko, H.Y., Lee, J.K., Shin, J.Y., \& Jo, E. (2015). Health-related Quality of Life and Cardiovascular Disease Risk in Korean Adults. Korean Journal of Family Medicine. 36: 349-356.

Lammintausta, A. (2013). Effects of socioeconomic status and sociodemographic features on cardiovascular disease mortality and morbidity in Finland. Turun Yliopiston Julkaisuja Annales Universitatis Turkuensis.

Ortiz, L.G., Rodriguez, J.L.R., Simon, S.M., Guillaumet, J., Marti, R., Conde, C.A., Sanchez, E.R., Fernandez, J.A.M., Blanes, R.R., Marcos, M.A.G. (2016). Vascular Structure and Function and Their Relationship with Health-related Quality of Life in the MARK study. BMC Cardiovascular Disorders. 16 (95):1-20.

Razaghi, N., Gazerani, A., Sadeghi, T. (2017). The Relationship between Mental Health and Spiritual Intelligence of Parents of Hospitalized Premature Neonates in the NICU. Journal of Pediatric and Neonatal Individualized Medicine. 6 (1): 1-8. 
Rochmayanti. (2011). Analisis Faktor-Faktor yang Mempengaruhi Kualitas Hidup Pasien Penyakit Jantung Koroner di Rumah Sakit Pelni Jakarta [karya tulis ilmiah]. Jakarta: Universitas Indonesia.

Sari, A., Lolita., Fauzia. (2017). Pengukuran Kualitas Hidup Pasien Hipertensi di Puskesmas Mergangsan Yogyakarta Menggunakan European Quality of Life 5 Dimensions (EQ5D) Questionnaire dan Visual Analog Scale (VAS). Jurnal Ilmiah Ibnu Sina. 2(1): $1-12$.

Sastroasmoro, S. \& Ismael, S. (2010). Dasar-dasar Metodologi Penelitian Klinis (edisi 3). Jakarta: Sagung Seto.

Sun, L,-Y., Lee, E,-W., Zahra, A., \& Park, J,-H. (2015). Risk Factors of Cardiovascular Disease and Their Related Socio-Economical, Environmental and Health Behavioral Factors: Focused on Low-Middle Income Countries- A Narrative Review Article. Iran Journal Public Health. 44 (4): 435-444.

Syalfina, A.D. (2017). Body Mass Index (BMI) dan Lama Menopause Berpengaruh terhadap Kualitas Hidup Menopause (Studi Di Desa Karang Jeruk Kecamatan Jatirejo Kabupaten Mojokerto). Hospital Majapahit. 9 (1): 28-42.

Ware, J.E., Kosinski, M., \& Keller, S.D. (1995). Sf-12: How to score the sf-12 physical and mental health summary scale (Edisi 2). Boston, MA: The Health Institute, New England Medical Center. Tersedia dari https://www.researchgate.net/publication/242636950_SF-12_How_to_Score_the_SF12_Physical_and_Mental_Health_Summary_Scales.

Wend, K.,Wend, P., \& Krum, S.A. (2012). Tissue-spesific of Loss Estrogen During Menopause and Aging. Frontiers in Endocrinology. 3: 1-14.

Wicaksana, A.L., Maharani, E., Hertanti, N.S. (2020). The Indonesian Version of the Medical Outcome Survey-Short Form Version 2 among Patients with Cardiovascular Diseases. International Journal of Nursing Practice. (early view).

World Health Organization. (2016). Cardiovascular diseases (cvds). Tersedia dari http://www.who.int/mediacentre/factsheets/fs317/en/.

Zimmerman, E., \& Woolf, S.H. (2014). Understanding the relationship between education and health. Washington, DC: Discussion Paper, Institute of Medicine. 